\title{
Effect of Cooling Rate on Phase and Crystal Morphology Transitions of $\mathrm{CaO}-\mathrm{SiO}_{2}$-Based Systems and $\mathrm{CaO}-\mathrm{Al}_{2} \mathrm{O}_{3}$-Based Systems
}

\author{
Mei Leng ${ }^{1,2}$, Feifei Lai ${ }^{1,2}$ and Jiangling $\mathrm{Li}^{1,2, *}$ \\ 1 College of Materials Science and Engineering, Chongqing University, Chongqing 400044, China; \\ 201809021083@cqu.edu.cn (M.L.); 20142953@cqu.edu.cn (F.L.) \\ 2 Chongqing Key Laboratory of Vanadium-Titanium Metallurgical and New Materials, Chongqing University, \\ Chongqing 400044, China \\ * Correspondence: lijiangling@cqu.edu.cn
}

Received: 19 November 2018; Accepted: 21 December 2018; Published: 25 December 2018

check for updates

\begin{abstract}
The phase and crystal morphology transitions of two typical types of mold fluxes were investigated fundamentally using differential scanning calorimetry (DSC) and confocal scanning laser microscopy (CSLM) techniques. For the traditional $\mathrm{CaO}-\mathrm{SiO}_{2}-\mathrm{CaF}_{2}-$ based mold flux, different cooling rates can change the phases and the crystal morphologies. Faceted cuspidine and $\mathrm{CaSiO}_{3}$ are co-precipitated when the cooling rate is less than $50{ }^{\circ} \mathrm{C} \cdot \mathrm{min}^{-1}$. The phases transform from $\mathrm{Ca}_{4} \mathrm{Si}_{2} \mathrm{O}_{7} \mathrm{~F}_{2}$ and $\mathrm{CaSiO}_{3}$ to $\mathrm{Ca}_{4} \mathrm{Si}_{2} \mathrm{O}_{7} \mathrm{~F}_{2}$ at the cooling rate of $50{ }^{\circ} \mathrm{C} \cdot \mathrm{min}^{-1}$. Cuspidine shows four different morphologies: faceted shape, fine stripe, fine stripe dendrite, and flocculent dendrite. The crystalline phases of $\mathrm{CaAl}_{2} \mathrm{O}_{4}$ and $\mathrm{Ca}_{3} \mathrm{~B}_{2} \mathrm{O}_{6}$ are co-precipitated in the $\mathrm{CaO}-\mathrm{Al}_{2} \mathrm{O}_{3}$-based mold flux. Neither the phases nor the crystal morphologies change in the low cooling rate range $\left(5^{\circ} \mathrm{C} \cdot \mathrm{min}^{-1}\right.$ to $50{ }^{\circ} \mathrm{C} \cdot \mathrm{min}^{-1}$ ). With decreasing temperature, the morphology of $\mathrm{CaAl}_{2} \mathrm{O}_{4}$ firstly becomes dendritic, and then the dendritic quality gradually changes to a large-mesh blocky shape at the cooling rates of $100{ }^{\circ} \mathrm{C} \cdot \mathrm{min}^{-1}, 200^{\circ} \mathrm{C} \cdot \mathrm{min}^{-1}$, and $500^{\circ} \mathrm{C} \cdot \mathrm{min}^{-1}$. Different cooling rates do not show an obvious impact on the morphology transition of $\mathrm{CaAl}_{2} \mathrm{O}_{4}$. The strong crystallization ability and large rate of crystallization affect the control of the heat transfer of the $\mathrm{CaO}-\mathrm{Al}_{2} \mathrm{O}_{3}$-based mold flux during casting. The big morphology difference between primary crystals of the $\mathrm{CaO}-\mathrm{SiO}_{2}-\mathrm{CaF}_{2}$-based mold flux and the $\mathrm{CaO}-\mathrm{Al}_{2} \mathrm{O}_{3}$-based mold flux is probably one of the biggest factors limiting lubrication between the $\mathrm{CaO}-\mathrm{Al}_{2} \mathrm{O}_{3}$-based mold flux and high- $\mathrm{Al}$ steel during casting.
\end{abstract}

Keywords: phase; crystal morphology; cooling rate; mold flux

\section{Introduction}

Mold fluxes, as one of the most important additives in the steelmaking process, play an indispensable role in continuous casting. During casting, molten fluxes infiltrate between the solidified shell and the copper mold. This has two main functions: one is to maintain good lubrication between the steel shell and the copper mold, and the other is to control the heat transfer from the steel shell to the mold. The functions of heat transfer and lubrication are deeply related to the surface quality of steel billets, especially at the initial stage of solidification during casting [1-3].

Mold fluxes form a slag film consisting of a liquid layer and solid layers between the solidifying steel shell and the copper mold. The solid layers include crystalline and glassy mold fluxes. The distribution and structure of the solid layers affect the control of the lubrication and heat transfer of the mold flux. As previously reported [4,5], the thermal resistance between the copper mold and the solidifying steel shell increases with increasing thickness of the solid slag film. The thickness 
of the solid layers is closely related to the crystallization behaviors. Many reports have shown that crystallization can reduce heat flux across the mold flux layer [6-8]. Hanao et al. [8] found that the reduction in heat transfer was caused by the formation of crystals of cuspidine in the flux film. Additionally, crystallization has a great effect on lubrication. It has been reported that the precipitation of crystals with a large size may decrease the lubrication ability of mold fluxes [9]. Therefore, proper crystallization behaviors are very important for better control of the heat transfer and lubrication properties of the mold flux.

The crystallization behaviors of a mold flux mainly include crystallization ability, crystallization temperature, crystal fraction, and crystal phase and morphology. Previous studies have focused on crystallization ability and temperature [10-12]. Consideration of the phase and crystal morphology transitions has been limited. Cho et al. [13] found that the size of the precipitated crystals affected the lubrication of the mold flux. Guo et al. [9] reported that the huge differences in crystal morphology between lime-silica-based mold fluxes and lime-alumina-based mold fluxes may be responsible for the poor lubrication performance of lime-alumina-based mold fluxes. In order to better control heat transfer and lubrication, it is necessary to investigate the changes in the phase and crystal morphology transitions of mold fluxes.

The cooling rate is the one of the most important factors affecting the crystallization behaviors of slag. Guo et al. [9] showed that the crystal morphology of a mold flux is highly related to supercooling. Zhang et al. [14] investigated the crystallization of a mold flux using temperature confocal scanning laser microscopy and found that the precipitated phase and crystal morphology had changed. Furthermore, Yoshiaki Kashiway et al. [15] reported that the liquid slag is exposed to different cooling paths, which can promote or prevent crystallization. Generally, high cooling rates are prone to generating glassy mold fluxes. Conversely, low cooling rates result in crystalized slags. Therefore, it is important to analyze the effect of the cooling rate on the phase and crystal morphology transitions of mold fluxes. There are many methods that have been employed to study crystallization $[14,16,17]$, such as differential scanning calorimetry (DSC), the double/single hot thermocouple technique (D/SHTT), confocal scanning laser microscopy (CSLM), and so on. To fill the gap due to the limited studies on crystal phases and morphologies, the effect of the cooling rate on the phase and crystal morphology transitions of two typical mold fluxes was identified in the present work.

A synthesized conventional $\mathrm{CaO}-\mathrm{SiO}_{2}-\mathrm{CaF}_{2}$-based mold flux and a nonreactive $\mathrm{CaO}-\mathrm{Al}_{2} \mathrm{O}_{3}$-based mold flux were investigated. The former is extensively used in steel production because of its good performance. The latter is regarded as a promising slag for high-[Al] steel casting [13]. However, the nonreactive $\mathrm{CaO}-\mathrm{Al}_{2} \mathrm{O}_{3}$-based mold flux is not used in actual production because of its poor performance. Crystallization behavior is one of the most important factors leading to poor performance of mold flux during casting. In the present work, we focused on investigating the phase and crystal morphology transitions of a conventional $\mathrm{CaO}-\mathrm{SiO}_{2}-\mathrm{CaF}_{2}$-based mold flux and a nonreactive $\mathrm{CaO}-\mathrm{Al}_{2} \mathrm{O}_{3}$-based mold flux at different cooling rates. A CSLM technique was used to analyze the crystallization behaviors at high cooling rates $\left(100-500{ }^{\circ} \mathrm{C} \cdot \mathrm{min}^{-1}\right)$ because it is easy to achieve a high cooling rate. DSC can determine the number of phases through the number of exothermic peaks present; this was used to analyze the crystallization behaviors at low cooling rates $\left(5-50{ }^{\circ} \mathrm{C} \cdot \mathrm{min}^{-1}\right)$.

\section{Materials and Method}

\subsection{Sample Preparation}

A traditional $\mathrm{CaO}-\mathrm{SiO}_{2}-\mathrm{CaF}_{2}$-based mold flux and a nonreactive $\mathrm{CaO}-\mathrm{Al}_{2} \mathrm{O}_{3}$-based mold flux were synthesized. Reagent-grade powders of $\mathrm{CaCO}_{3}, \mathrm{Na}_{2} \mathrm{CO}_{3}, \mathrm{H}_{3} \mathrm{BO}_{3}, \mathrm{CaF}_{2}, \mathrm{SiO}_{2}$, and $\mathrm{Al}_{2} \mathrm{O}_{3}$ were used as the raw materials. In order to obtain $\mathrm{CaO}, \mathrm{CaCO}_{3}$ was calcined at $1373 \mathrm{~K}\left(1100{ }^{\circ} \mathrm{C}\right)$ in a muffle furnace (Nuobadi Corporation, Zhengzhou, China) and held for $8 \mathrm{~h}$; it was identified by calculating the weight loss before and after the experiment. The chemical compositions of the investigated mold fluxes are listed in Table 1. 
Table 1. The chemical compositions of the investigated mold fluxes.

\begin{tabular}{ccccccc}
\hline \multirow{2}{*}{ Sample No. } & \multicolumn{7}{c}{ Composition (mass\%) } \\
\cline { 2 - 7 } & $\mathrm{CaO}$ & $\mathrm{SiO}_{\mathbf{2}}$ & $\mathbf{A l}_{\mathbf{2}} \mathbf{O}_{\mathbf{3}}$ & $\mathbf{N a}_{\mathbf{2}} \mathbf{O}$ & $\mathrm{CaF}_{\mathbf{2}}$ & $\mathbf{B}_{\mathbf{2}} \mathbf{O}_{\mathbf{3}}$ \\
\hline 1 & 36 & 36 & 5 & 8 & 15 & 0 \\
2 & 42 & 0 & 42 & 8 & 0 & 8 \\
\hline
\end{tabular}

The glassy samples were prepared by the conventional melting and water-quenching method. The mixed sample was placed in a platinum crucible and melted in a high-temperature furnace with molybdenum silicide as the heating element at approximately $1623 \mathrm{~K}\left(1350^{\circ} \mathrm{C}\right)$. In order to achieve complete melting and homogenization, the mold flux samples were held at $1623 \mathrm{~K}\left(1350{ }^{\circ} \mathrm{C}\right)$ for $2 \mathrm{~h}$. Then, they were quenched with water. The quenched samples were characterized by X-ray diffraction (XRD), as shown in Figure 1. Both exhibited amorphous properties.

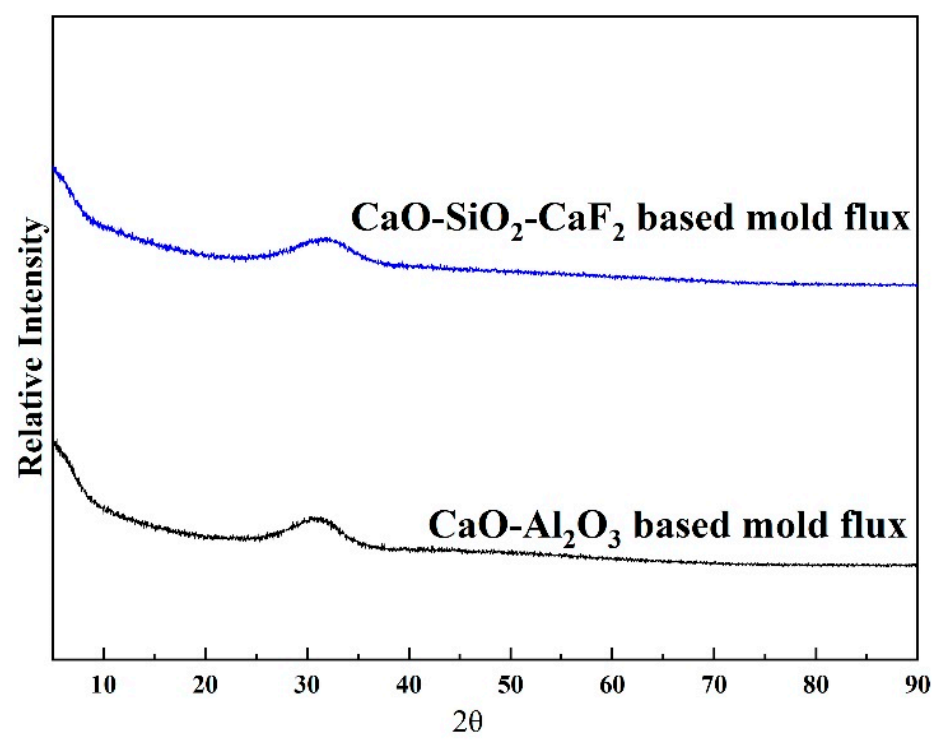

Figure 1. X-ray diffraction patterns of glassy mold fluxes of a $\mathrm{CaO}-\mathrm{SiO}_{2}-\mathrm{CaF}_{2}$-based mold flux and a $\mathrm{CaO}-\mathrm{Al}_{2} \mathrm{O}_{3}$-based mold flux.

\subsection{Differential Scanning Calorimetry (Cooling Rate: $0-50^{\circ} \mathrm{C} \cdot \mathrm{min}^{-1}$ )}

The glassy samples were pulverized into powder for differential scanning calorimetry analysis (DSC) with cooling rates ranging from $0{ }^{\circ} \mathrm{C} \cdot \mathrm{min}^{-1}$ to $50{ }^{\circ} \mathrm{C} \cdot \mathrm{min}^{-1}$. The differential scanning calorimetry analysis was performed in an argon atmosphere on each of the glassy samples over the range of $773-1723 \mathrm{~K}\left(500-1350{ }^{\circ} \mathrm{C}\right)$ using a Netzsch DSC404 F3 calorimeter (Netzsch Corporation, Selb, Germany). Alfa- $\mathrm{Al}_{2} \mathrm{O}_{3}$ was used as a reference material for the DSC experiments.

\subsection{Confocal Scanning Laser Microscopy (Cooling Rate: $100-50^{\circ} \mathrm{C} \cdot \mathrm{min}^{-1}$ )}

In situ observation of crystallization was performed using a halogen lamp heating stage and a confocal scanning laser microscope (CSLM, VL2000DX, Lasertec Corporation, Yokohama, Japan). The platinum crucible containing the samples was rapidly heated by the light irradiated by the halogen lamp. In the cooling process, the crystallization phenomena were recorded by in situ observation of the surface of the slags. After the sample reached thermal equilibrium, the melt was cooled at a designated rate, and video images of the molten slag were collected during the non-isothermal stage. The nucleation and growth process of the crystals in the investigated mold fluxes were observed during continuous cooling of the slag at fixed rates from 100 to $500{ }^{\circ} \mathrm{C} \cdot \mathrm{min}^{-1}$. 


\subsection{Phase and Crystal Morphology Identification}

The crystalline phase and crystal morphology of the samples after DSC and CSLM measurements were identified by X-ray diffraction (XRD) and a scanning electron microscope equipped with energy-dispersive $\mathrm{X}$-ray spectroscopy (SEM-EDS) for microanalysis. Powder X-ray diffraction measurements were carried out on an 18KW X-ray diffractometer (RIGAKU TTR III, Rigaku Corporation, Tokyo, Japan). SEM examinations were carried out using a TESCAN VEGA 3 LMH (TESCAN Corporation, Brno, Czech Republic) equipped with EDS.

\section{Discussion and Results}

\subsection{Effect of Cooling Rate on the Phase and Crystal Morphology Transitions of the CaO-SiO${ }_{2}-\mathrm{CaF}_{2}-\mathrm{Based}$} Mold Flux

The crystallization behaviors of the $\mathrm{CaO}-\mathrm{SiO}_{2}-\mathrm{CaF}_{2}$-based mold flux were investigated at different cooling rates using DSC and CSLM. The specific cooling rates are shown in Figure 2a. The DSC curves of non-isothermal crystallization of $\mathrm{CaO}-\mathrm{SiO}_{2}-\mathrm{CaF}_{2}$-based mold fluxes at the cooling rates of $5{ }^{\circ} \mathrm{C} \cdot \mathrm{min}^{-1}$, $30^{\circ} \mathrm{C} \cdot \mathrm{min}^{-1}$, and $50^{\circ} \mathrm{C} \cdot \mathrm{min}^{-1}$ are shown in Figure $3 \mathrm{a}$. It can be seen that there were two exothermic peaks on the DSC curves at the cooling rates of $5^{\circ} \mathrm{C} \cdot \mathrm{min}^{-1}$ and $30{ }^{\circ} \mathrm{C} \cdot \mathrm{min}^{-1}$, and only one exothermic peak at the cooling rate of $50^{\circ} \mathrm{C} \cdot \mathrm{min}^{-1}$. This indicated the presence of two successive crystallization events for the $\mathrm{CaO}-\mathrm{SiO}_{2}-\mathrm{CaF}_{2}$-based mold flux at the cooling rates of $5^{\circ} \mathrm{C} \cdot \mathrm{min}^{-1}$ and $30^{\circ} \mathrm{C} \cdot \mathrm{min}^{-1}$, and only one crystallization event occurring at the cooling rate of $50{ }^{\circ} \mathrm{C} \cdot \mathrm{min}^{-1}$. Additionally, it was observed that the exothermic peaks on the DSC curves moved toward a lower temperature and the shape of exothermic peak became sharper with the increasing cooling rate. This may be attributed to the fact that the nucleation and growth rate of crystals are functions of viscosity and undercooling. Viscosity increases quickly under a high cooling rate, and a stronger driving force is required to initiate the mold flux nucleation [18]. The specific change in the crystallization temperature is shown in Figure 3b. It can be concluded that the crystallization temperature decreased with increasing cooling rate in the $\mathrm{CaO}-\mathrm{SiO}_{2}-\mathrm{CaF}_{2}$-based mold flux. The crystallization behaviors of the $\mathrm{CaO}-\mathrm{SiO}_{2}-\mathrm{CaF}_{2}$-based mold flux were previously investigated by SEO et al. [19] by employing a DSC technique. They also found similar behaviors in the crystallization.

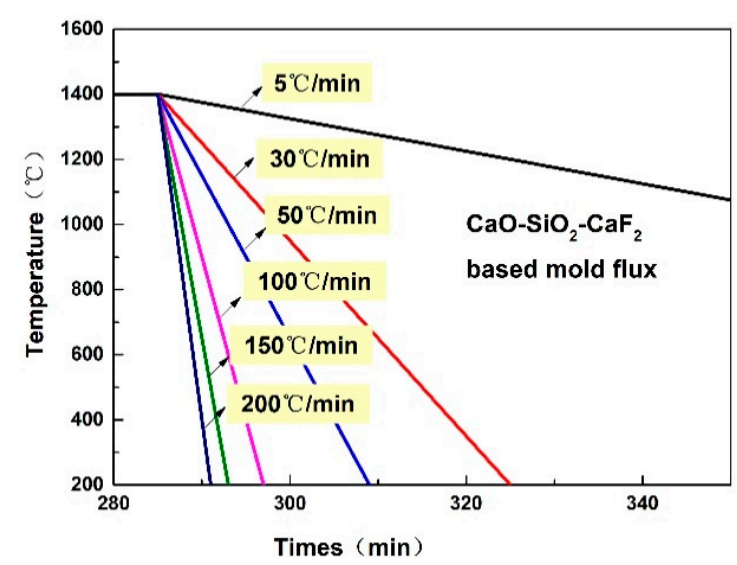

(a)

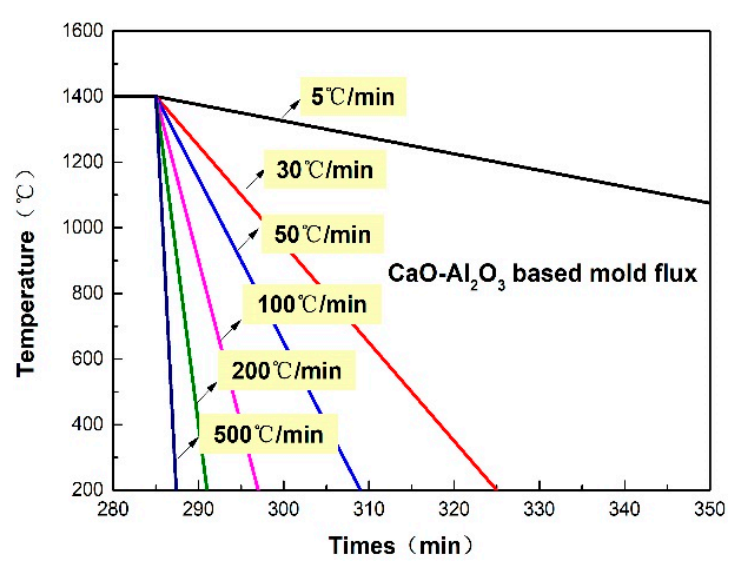

(b)

Figure 2. A diagram of the cooling process at different cooling rates in (a) a $\mathrm{CaO}-\mathrm{SiO}_{2}-\mathrm{CaF}_{2}-$ based mold flux and (b) a CaO- $\mathrm{Al}_{2} \mathrm{O}_{3}$-based mold flux. 


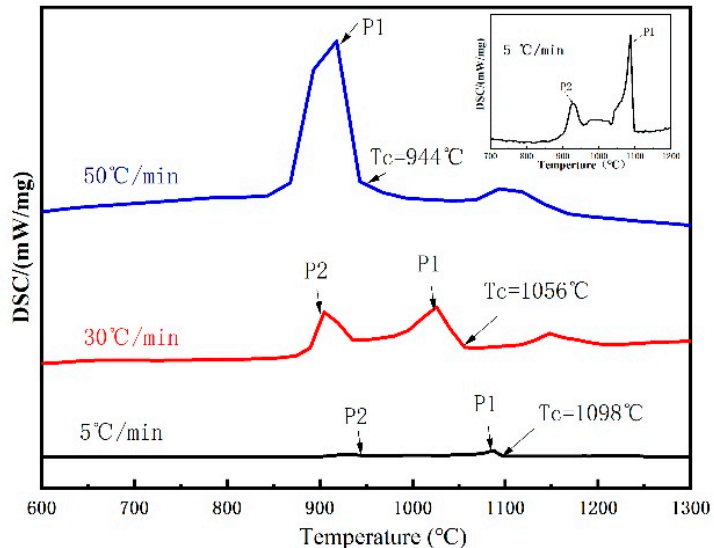

(a)

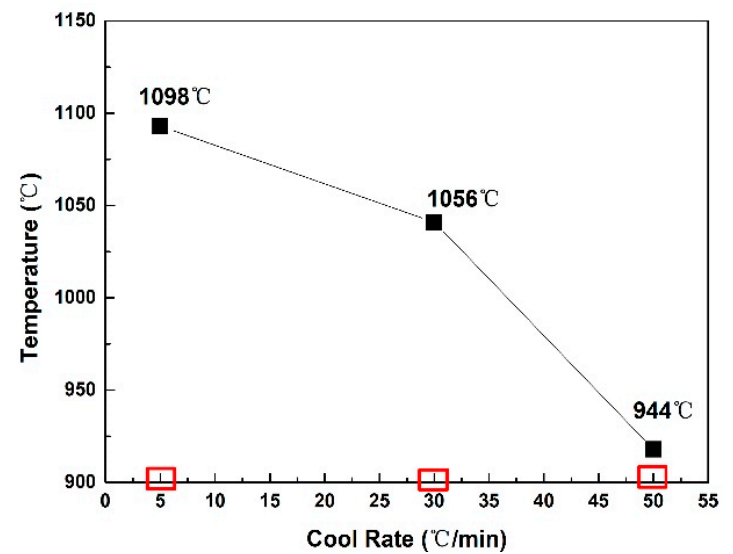

(b)

Figure 3. (a) Differential scanning calorimetry (DSC) curves of the non-isothermal crystallization of $\mathrm{CaO}-\mathrm{SiO}_{2}-\mathrm{CaF}_{2}$-based mold fluxes at the cooling rates of $5^{\circ} \mathrm{C} \cdot \mathrm{min}^{-1}, 30^{\circ} \mathrm{C} \cdot \mathrm{min}^{-1}$, and $50^{\circ} \mathrm{C} \cdot \mathrm{min}^{-1}$. (b) The crystallization temperatures at the cooling rates of $5^{\circ} \mathrm{C} \cdot \mathrm{min}^{-1}, 30^{\circ} \mathrm{C} \cdot \mathrm{min}^{-1}$, and $50{ }^{\circ} \mathrm{C} \cdot \mathrm{min}^{-1}$.

In order to identify the phases and crystal morphologies, the samples taken from the DSC measurements were characterized by SEM-EDS, as shown in Figure 4. The main phase was identified as cusipdine $\left(\mathrm{CaO} \cdot 2 \mathrm{SiO}_{2} \cdot \mathrm{CaF}_{2}\right)$ at all cooling rates. According to the phase equilibrium study on the $\mathrm{CaO}-\mathrm{CaF}_{2}-\mathrm{SiO}_{2}-\mathrm{Al}_{2} \mathrm{O}_{3}$ flux system carried out by the present author [20], cuspidine, as the primary crystal in mold fluxes with basicity higher than $\mathrm{R}=1\left(\mathrm{R}=\mathrm{CaO}\right.$ mass $\% / \mathrm{SiO}_{2}$ mass $\left.\%\right)$, was firstly formed. The main morphology of cuspidine was faceted at the cooling rates of $5^{\circ} \mathrm{C} \cdot \mathrm{min}^{-1}$ and $30^{\circ} \mathrm{C} \cdot \mathrm{min}^{-1}$. When the cooling rate increased to $50{ }^{\circ} \mathrm{C} \cdot \mathrm{min}^{-1}$, the morphology of cuspidine changed to fine stripe. It can be concluded that a high cooling rate could induce a morphology transition in the crystallized cuspidine. In addition, the phases decreased with the increasing cooling rate.

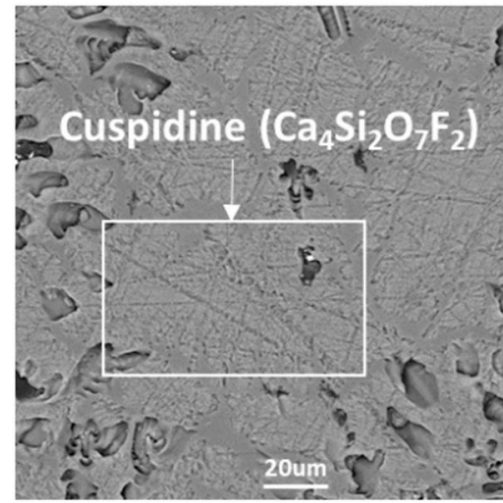

(a)

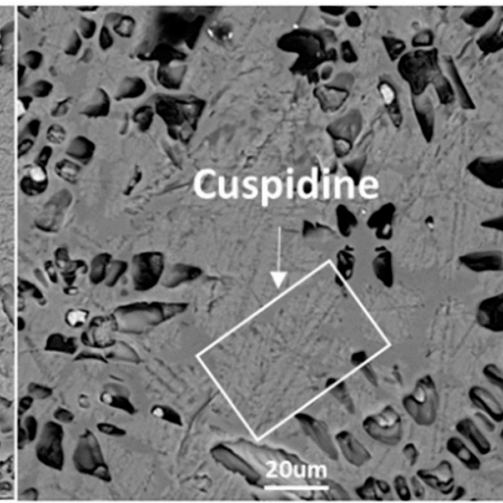

(b)

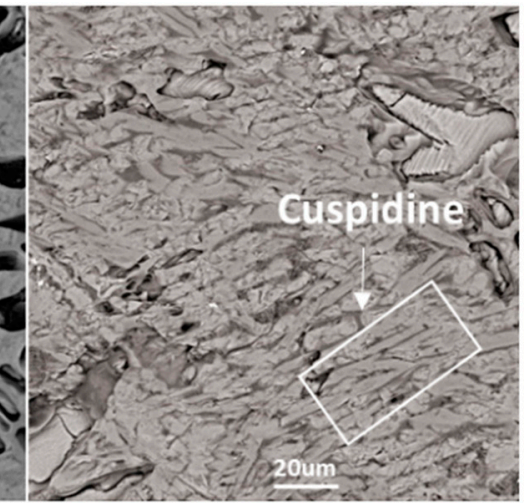

(c)

Figure 4. Scanning electron microscope (SEM) micrographs of the $\mathrm{CaO}-\mathrm{SiO}_{2}-\mathrm{CaF}_{2}$-based mold flux after DSC measurements: (a) $5^{\circ} \mathrm{C} \cdot \mathrm{min}^{-1}$, (b) $30^{\circ} \mathrm{C} \cdot \mathrm{min}^{-1}$, and (c) $50{ }^{\circ} \mathrm{C} \cdot \mathrm{min}^{-1}$.

Because the phase identification by SEM-EDS after the DSC measurements of the $\mathrm{CaO}-\mathrm{SiO}_{2}-\mathrm{CaF}_{2}$-based mold flux could not determine the corresponding crystalline phases of the two exothermic peaks, heat treatment experiments were carried out to analyze the crystalline phase precipitation in the mold fluxes at the cooling rate of $5^{\circ} \mathrm{C} \cdot \mathrm{min}^{-1}$. After the heat treatment experiments, the samples were subjected to XRD analysis to identify the specific crystalline phase. The results are shown in Figure 5. It was seen that cuspidine and $\mathrm{CaSiO}_{3}$ co-precipitated in the $\mathrm{CaO}-\mathrm{SiO}_{2}-\mathrm{CaF}_{2}$-based mold flux. The fact that only cuspidine was observed in SEM may be because the second phase, that is, $\mathrm{CaSiO}_{3}$, precipitated at a lower temperature with a small crystal size. 


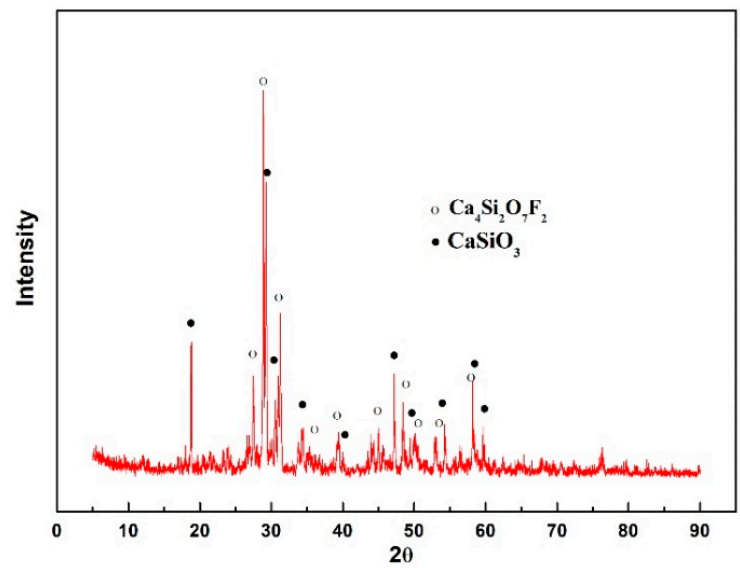

Figure 5. X-ray diffraction (XRD) patterns of the $\mathrm{CaO}-\mathrm{SiO}_{2}-\mathrm{CaF}_{2}$-based mold flux at the cooling rate of $5{ }^{\circ} \mathrm{C} \cdot \mathrm{min}^{-1}$.

The effect of high cooling rates on the phase and crystal morphology transitions of the $\mathrm{CaO}-\mathrm{SiO}_{2}-\mathrm{CaF}_{2}$-based mold flux was analyzed by CSLM. Figure 6a-c show the crystallization process of slag at the cooling rates of $100{ }^{\circ} \mathrm{C} \cdot \mathrm{min}^{-1}, 150^{\circ} \mathrm{C} \cdot \mathrm{min}^{-1}$, and $20{ }^{\circ} \mathrm{C} \cdot \mathrm{min}^{-1}$, respectively. As we know, liquid fluxes present as a bright white field in CSLM experiments. It was observed that the primary phase precipitated from the molten fluxes, then started to develop, and the liquid phase gradually reduced as the temperature gradually decreased. When the cooling rate was increased to $200{ }^{\circ} \mathrm{C} \cdot \mathrm{min}^{-1}$, there was no crystallization observed throughout the whole cooling process. The onset of the nucleation and growth of primary crystals is shown in Figure 6a,b. It was observed that the morphology of cuspidine was the blocky shape. When the temperature gradually decreased, distinct dendrites were observed in the blocky-shaped crystal. It was further confirmed by the SEM results in Figure $7 \mathrm{a}$ that cuspidine presented fine stripe dendrites at the cooling rate of $100{ }^{\circ} \mathrm{C} \cdot \mathrm{min}^{-1}$. This is similar to the morphology of cuspidine at the cooling rate of $50{ }^{\circ} \mathrm{C} \cdot \mathrm{min}^{-1}$. When the cooling rate was increased to $150{ }^{\circ} \mathrm{C} \cdot \mathrm{min}^{-1}$, the morphology of the cuspidine transformed to the flocculent dendrite shape.

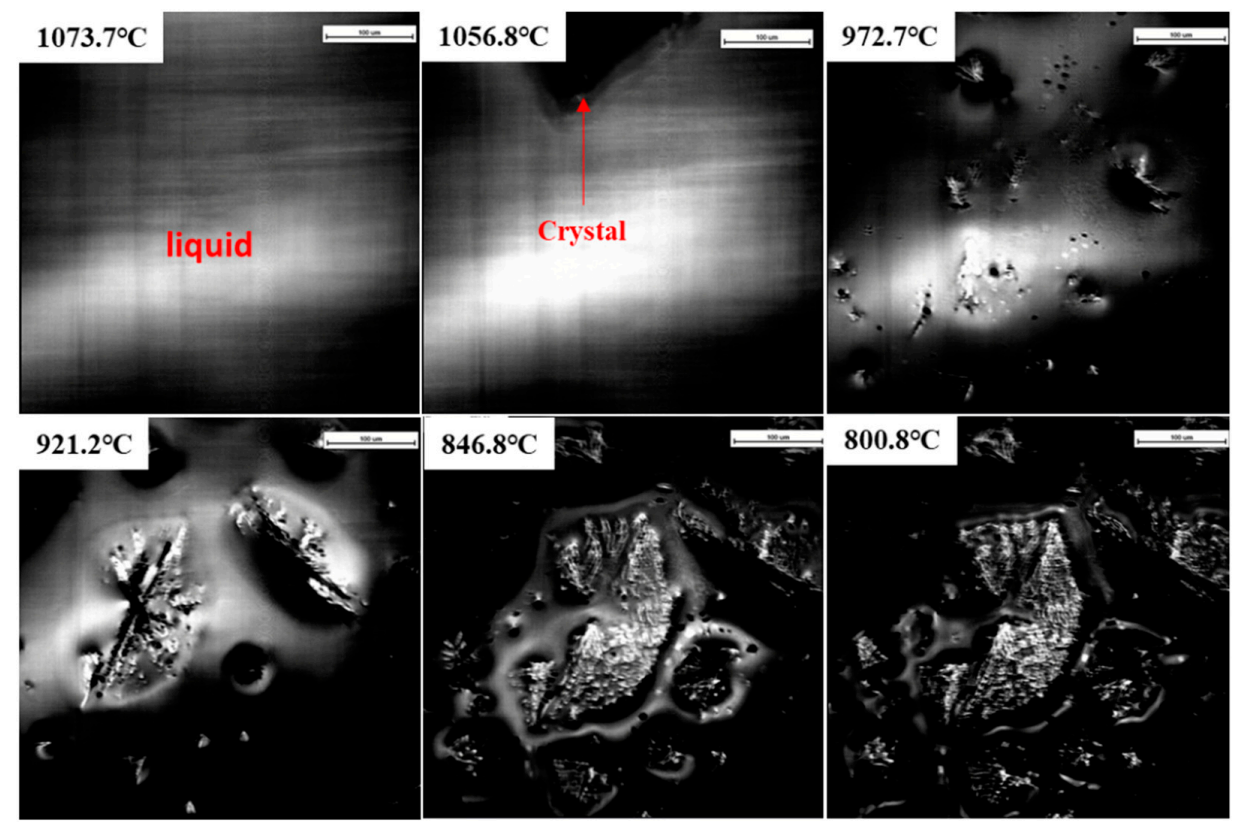

(a)

Figure 6. Cont. 


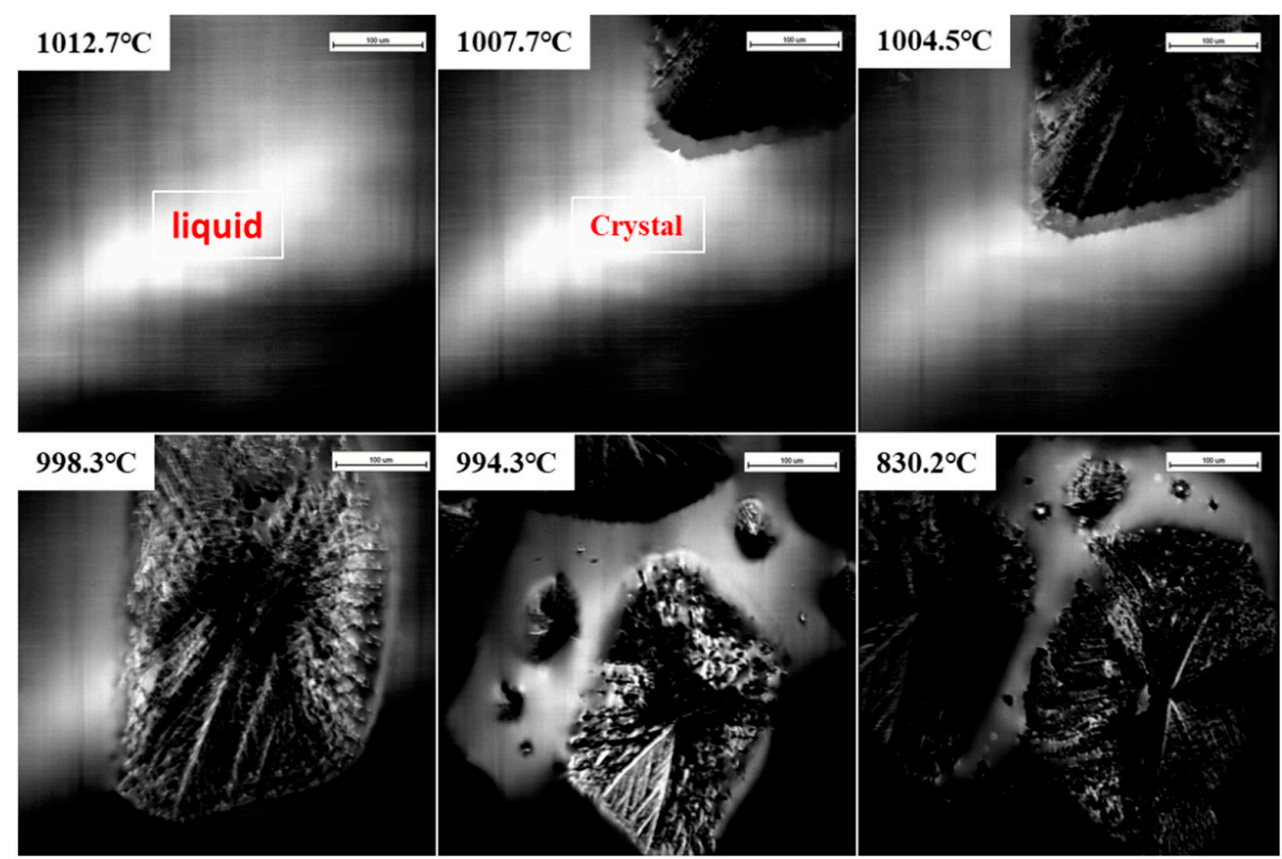

(b)

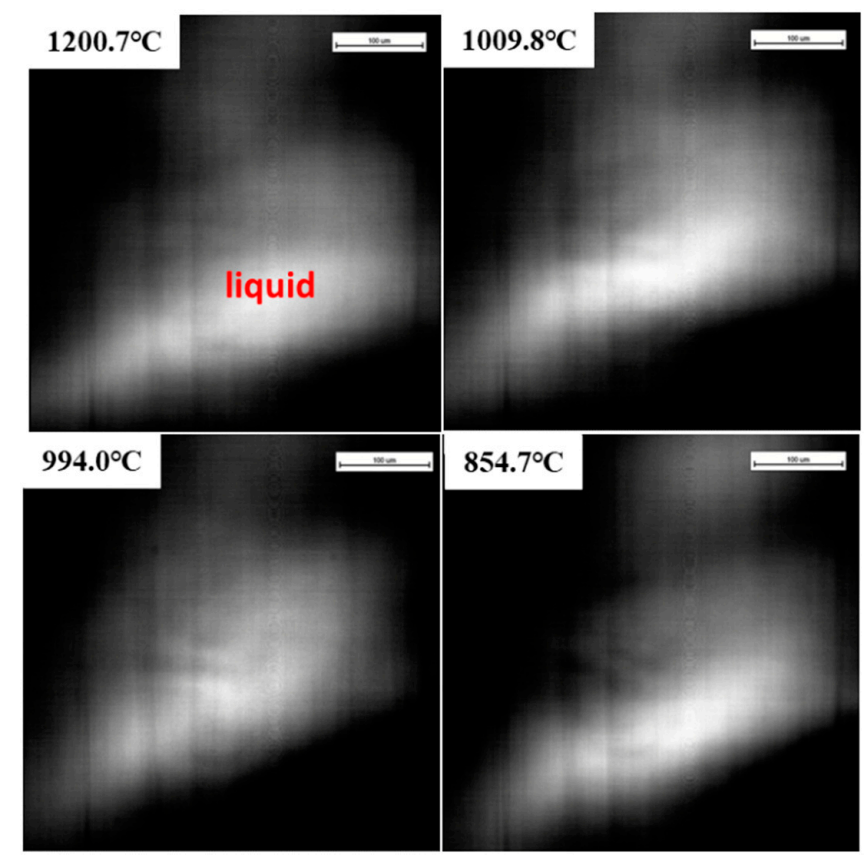

(c)

Figure 6. The crystallization process of the $\mathrm{CaO}-\mathrm{SiO}_{2}-\mathrm{CaF}_{2}$-based mold flux measured by confocal scanning laser microscopy (CSLM) at different cooling rates: (a) $100^{\circ} \mathrm{C} \cdot \mathrm{min}^{-1}$, (b) $150^{\circ} \mathrm{C} \cdot \mathrm{min}^{-1}$, and (c) $200^{\circ} \mathrm{C} \cdot \mathrm{min}^{-1}$. 


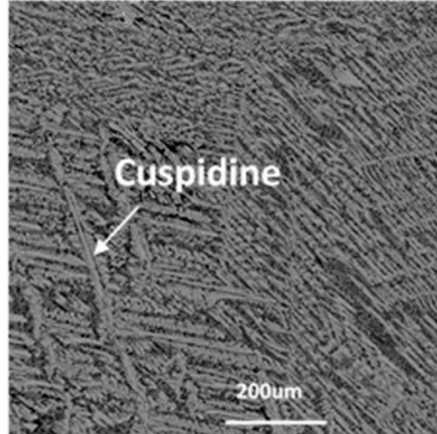

(a)

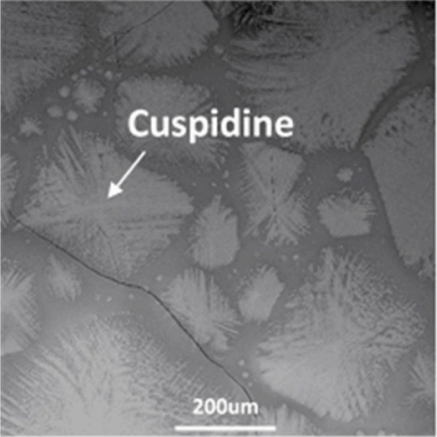

(b)

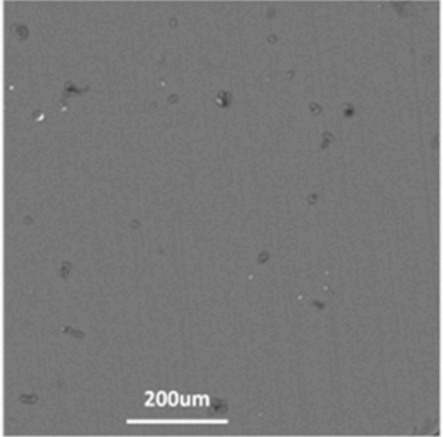

(c)

Figure 7. SEM micrographs of the $\mathrm{CaO}-\mathrm{SiO}_{2}-\mathrm{CaF}_{2}$-based mold fluxes after confocal scanning laser microscopy (CSLM) measurements at different cooling rates: (a) $100^{\circ} \mathrm{C} \cdot \mathrm{min}^{-1}$, (b) $150{ }^{\circ} \mathrm{C} \cdot \mathrm{min}^{-1}$, and (c) $200{ }^{\circ} \mathrm{C} \cdot \mathrm{min}^{-1}$.

It can be concluded from the DSC and CSLM results that different cooling rates can change the phase and crystallization morphology of a $\mathrm{CaO}-\mathrm{SiO}_{2}-\mathrm{CaF}_{2}$-based mold flux. The phases transform from $\mathrm{Ca}_{4} \mathrm{Si}_{2} \mathrm{O}_{7} \mathrm{~F}_{2}$ and $\mathrm{CaSiO}_{3}$ to $\mathrm{Ca}_{4} \mathrm{Si}_{2} \mathrm{O}_{7} \mathrm{~F}_{2}$ as the cooling rate increases from $30^{\circ} \mathrm{C} \cdot \mathrm{min}^{-1}$ to $50{ }^{\circ} \mathrm{C} \cdot \mathrm{min}^{-1}$. Cuspidine shows four different morphologies: faceted shape, fine stripe, fine stripe dendrite, and flocculent dendrite. Many researchers have studied the morphology of crystal [2,9,18,21-24]. Lu et al. [21] studied the crystal morphology transitions relating to different supercooling degrees of $\mathrm{Ni}-\mathrm{Si}$ alloy melt and found that the crystal morphology of the alpha-Ni phase transformed from non-faceted to faceted in morphology when the supercooling was larger than approximately $390^{\circ} \mathrm{C}$, while it tended to be dendritic again when the supercooling increased to around $500{ }^{\circ} \mathrm{C}$. Orrling et al. [23] investigated the crystallization of slags using a double hot thermocouple technique and found that the crystal morphology was deeply related to the experimental temperature. They found four different morphologies of crystals (equiaxed crystal at high temperature, columnar crystals from thermocouple towards center, faceted crystals, and fine crystals) based on the melting undercooling. The crystallization process is very complex and is controlled by nucleation and crystal growth. The crystal morphology is mainly governed by the crystal growth process after nucleation $[9,25]$. There are two important factors that affect crystal growth: one is the elements diffusing from the melt bulk to the crystal-melt interface, and the other is the chemical reactions that occur at the interface. If the crystal growth is controlled by chemical reactions, then the crystal morphology is more likely to be faceted, while it will tend to be dendritic if the crystal growth is determined by the element diffusion process. The chemical reaction rate is proportional to the driving force, and the element diffusion rate is inversely proportional to the viscosity of the melts $[9,25]$. This indicates that the crystal morphology transition is influenced by the supercooling degree. When the supercooling degree increases, the controlling step alters from chemical reaction at the interface to element diffusion at the interface, because the viscosity of the melt increases greatly with increasing supercooling. This phenomenon can explain the present results concerning the transition of crystal morphology from faceted to dendritic with the increasing cooling rate.

\subsection{Effect of Cooling Rate on Phase and Crystal Morphology Transitions of the $\mathrm{CaO}-\mathrm{Al}_{2} \mathrm{O}_{3}$-Based Mold Flux}

The crystallization behaviors of a $\mathrm{CaO}-\mathrm{Al}_{2} \mathrm{O}_{3}$-based mold flux were investigated at different cooling rates using DSC and CSLM. The specific cooling rates are shown in Figure $2 \mathrm{~b}$. The DSC and CSLM results are shown in Figures 8 and 9, respectively, and the corresponding XRD and SEM-EDS analysis results are shown in Figures 10-12. It can be seen in Figure 8a that there were two exothermic peaks on the DSC curves for samples at different cooling rates. This indicated the presence of two successive crystallization events for the $\mathrm{CaO}-\mathrm{Al}_{2} \mathrm{O}_{3}$-based mold flux at different cooling rates. The crystallization temperatures were determined and are shown in Figure 8b. It can 
be seen that the crystallization temperature decreased from $1240{ }^{\circ} \mathrm{C}$ to $1112{ }^{\circ} \mathrm{C}$ as the cooling rate increased from $5{ }^{\circ} \mathrm{C} \cdot \mathrm{min}^{-1}$ to $50^{\circ} \mathrm{C} \cdot \mathrm{min}^{-1}$. SEM-EDS combined with XRD analysis showed that $\mathrm{CaAl}_{2} \mathrm{O}_{4}$ and $\mathrm{Ca}_{3} \mathrm{~B}_{2} \mathrm{O}_{6}$ co-precipitated. The crystal morphology of the samples identified by SEM-EDS after DSC measurements is shown in Figure 10. The primary phase was identified as $\mathrm{CaAl}_{2} \mathrm{O}_{4}$ at all cooling rates. Because the second phase, that is, $\mathrm{Ca}_{3} \mathrm{~B}_{2} \mathrm{O}_{6}$, precipitated at a lower temperature with a small crystal size, it could not be detected. The main morphology of $\mathrm{CaAl}_{2} \mathrm{O}_{4}$ was a big blocky shape, and it did not change at cooling rates between $30^{\circ} \mathrm{C} \cdot \mathrm{min}^{-1}$ and $50{ }^{\circ} \mathrm{C} \cdot \mathrm{min}^{-1}$. Shi et al. [26] investigated the crystallization behaviors of a $\mathrm{CaO}-\mathrm{Al}_{2} \mathrm{O}_{3}$-based mold flux and found that the precipitated calcium aluminate crystals are the primary phase and appear as a blocky shape. This is similar to our present results. It can be concluded that the phases and crystal morphologies are not altered by cooling rates between $30^{\circ} \mathrm{C} \cdot \mathrm{min}^{-1}$ and $50^{\circ} \mathrm{C} \cdot \mathrm{min}^{-1}$.

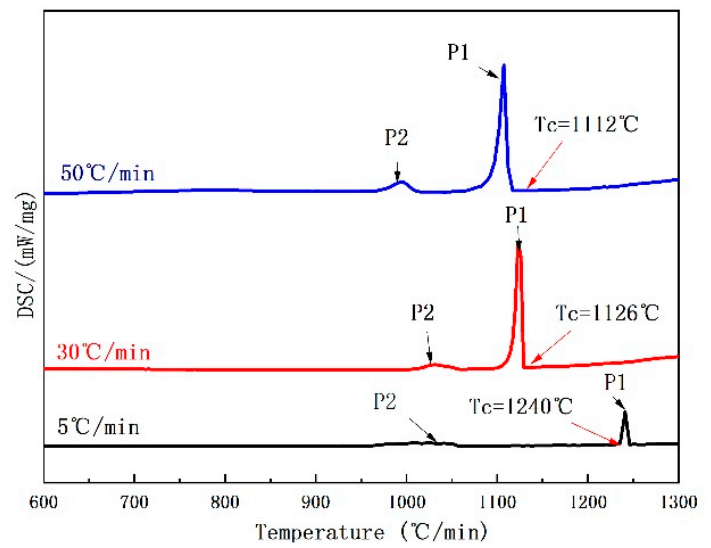

(a)

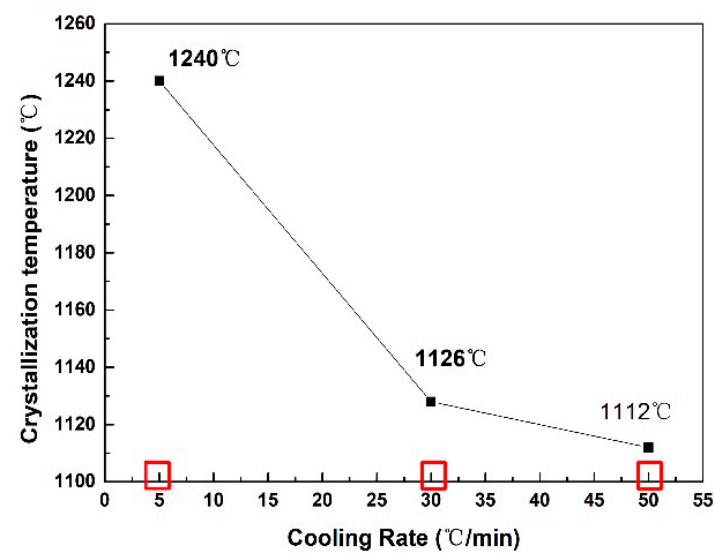

(b)

Figure 8. (a) DSC curves of non-isothermal crystallization of the $\mathrm{CaO}-\mathrm{Al}_{2} \mathrm{O}_{3}$-based mold flux at the cooling rates of $5^{\circ} \mathrm{C} \cdot \mathrm{min}^{-1}, 30^{\circ} \mathrm{C} \cdot \mathrm{min}^{-1}$, and $50^{\circ} \mathrm{C} \cdot \mathrm{min}^{-1}$. (b) The crystallization temperatures at the cooling rates of $5^{\circ} \mathrm{C} \cdot \mathrm{min}^{-1}, 30^{\circ} \mathrm{C} \cdot \mathrm{min}^{-1}$, and $50{ }^{\circ} \mathrm{C} \cdot \mathrm{min}^{-1}$.

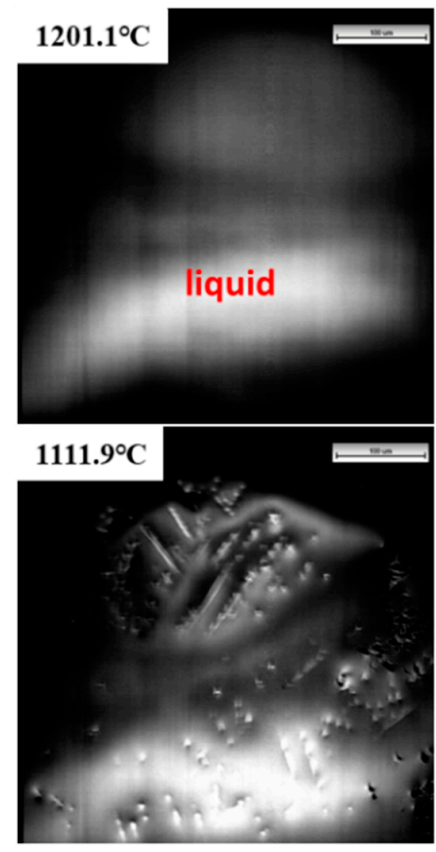

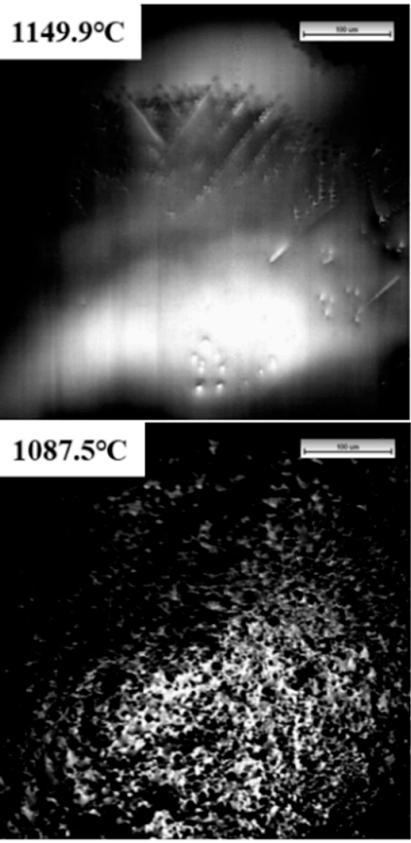

(a)

Figure 9. Cont. 


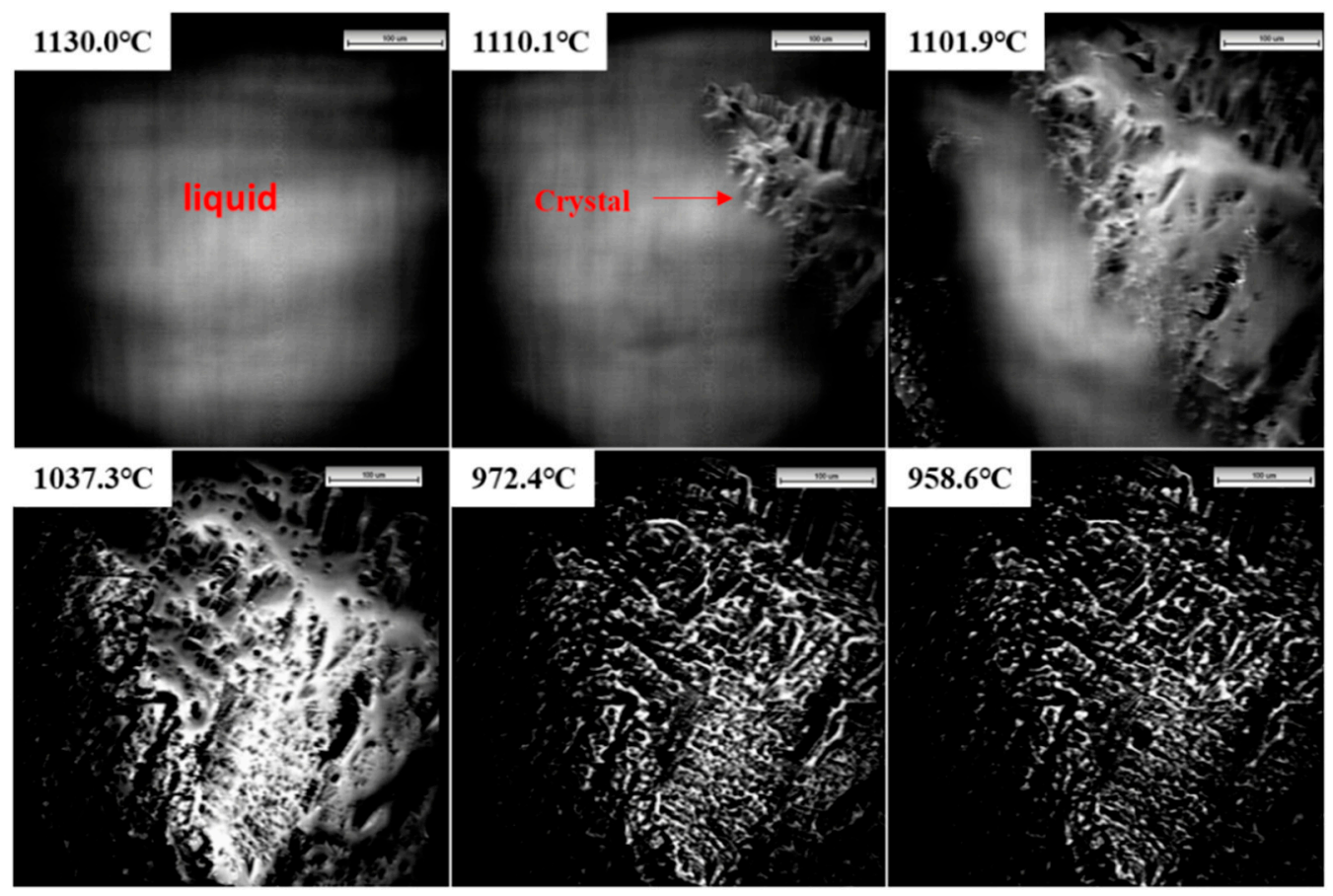

(b)

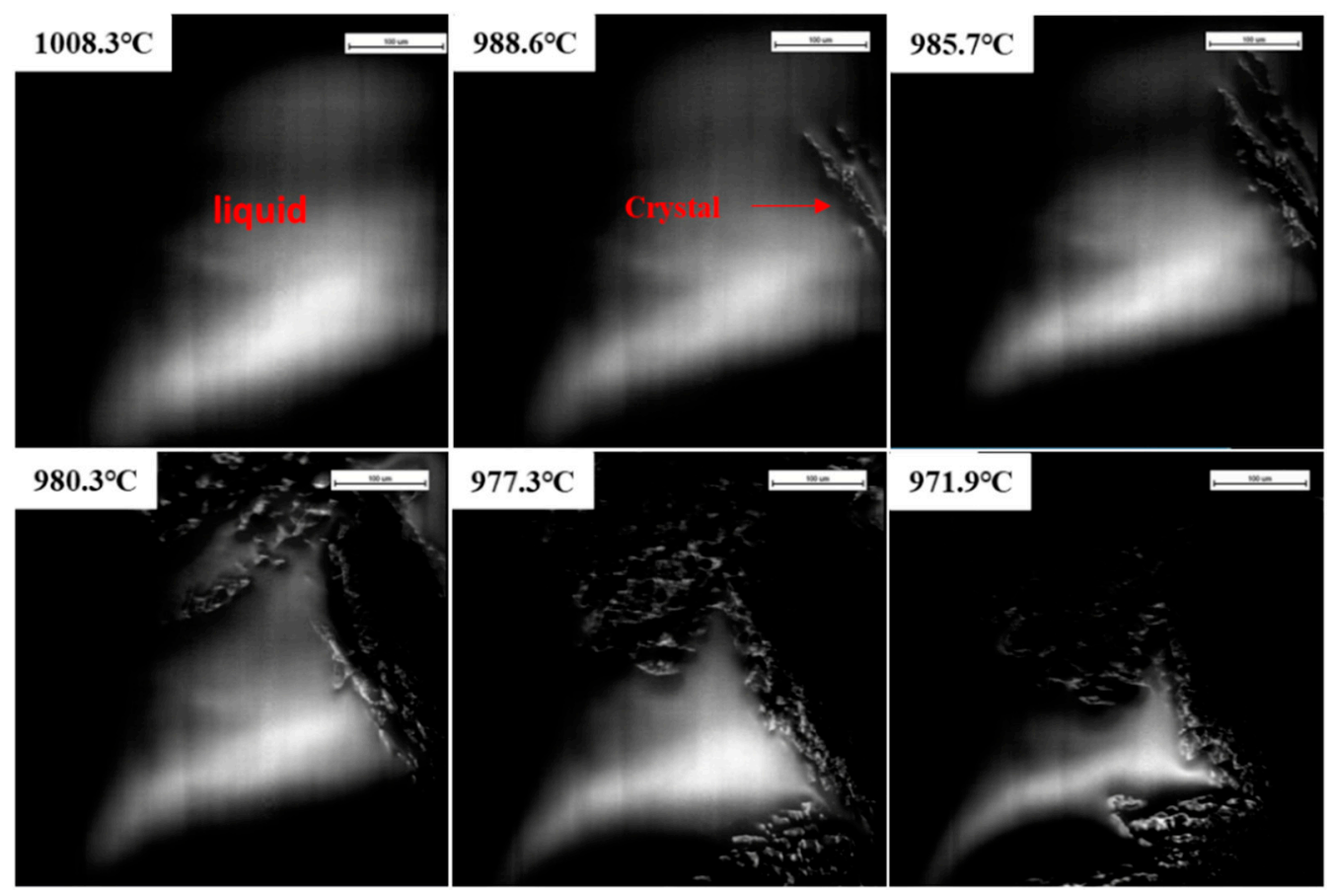

(c)

Figure 9. The crystallization process of the $\mathrm{CaO}-\mathrm{Al}_{2} \mathrm{O}_{3}$-based mold flux measured by CSLM at different cooling rates: (a) $100{ }^{\circ} \mathrm{C} \cdot \mathrm{min}^{-1}$, (b) $300{ }^{\circ} \mathrm{C} \cdot \mathrm{min}^{-1}$, and (c) $500^{\circ} \mathrm{C} \cdot \mathrm{min}^{-1}$. 


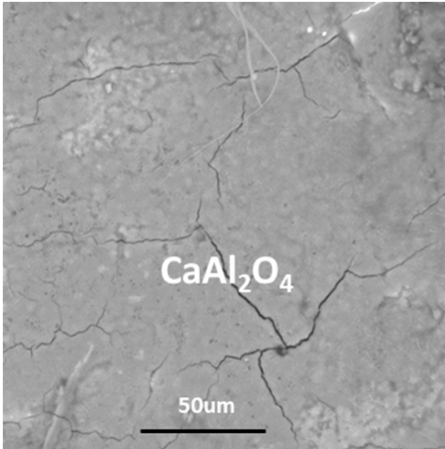

(a)

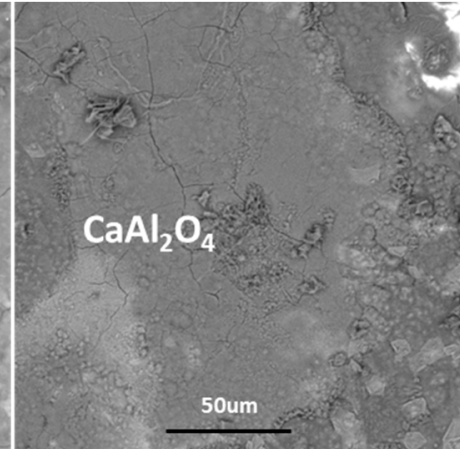

(b)

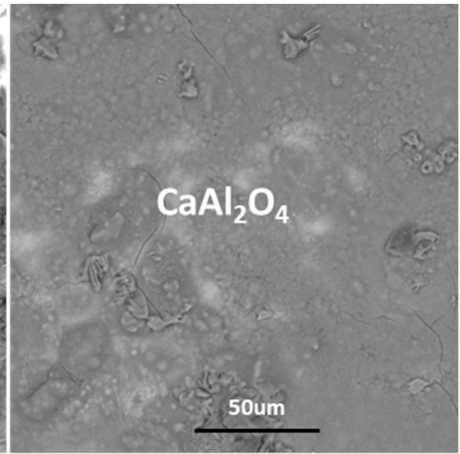

(c)

Figure 10. SEM micrographs of the $\mathrm{CaO}-\mathrm{Al}_{2} \mathrm{O}_{3}$-based mold flux after DSC measurements: (a) 5 ${ }^{\circ} \mathrm{C} \cdot \mathrm{min}^{-1},(\mathbf{b}) 30^{\circ} \mathrm{C} \cdot \mathrm{min}^{-1}$, and (c) $50^{\circ} \mathrm{C} \cdot \mathrm{min}^{-1}$.

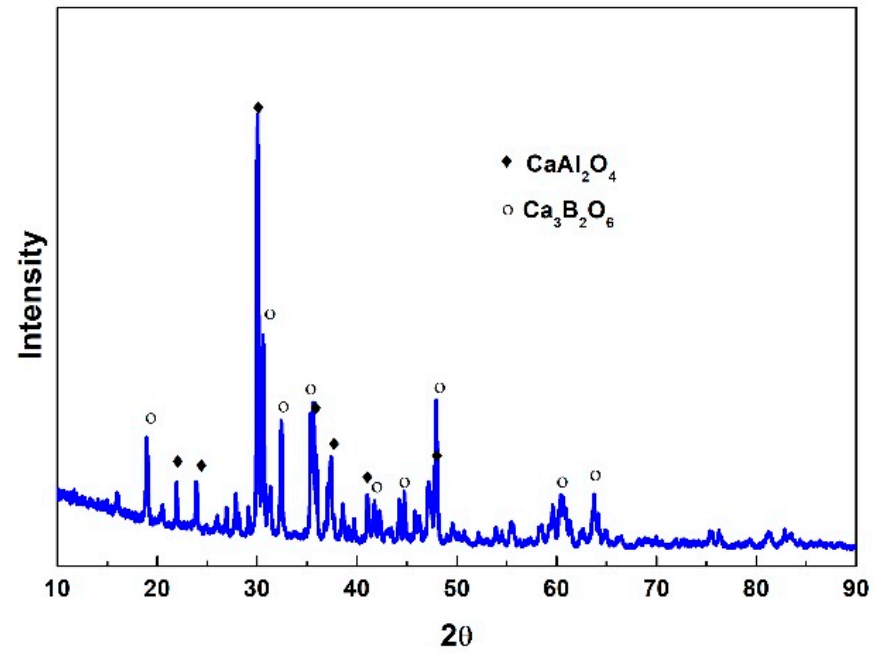

Figure 11. XRD patterns of the $\mathrm{CaO}-\mathrm{Al}_{2} \mathrm{O}_{3}$-based mold flux at the cooling rate of $5{ }^{\circ} \mathrm{C} \cdot \mathrm{min}^{-1}$.

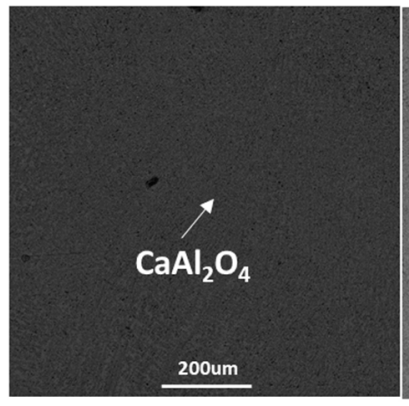

(a)

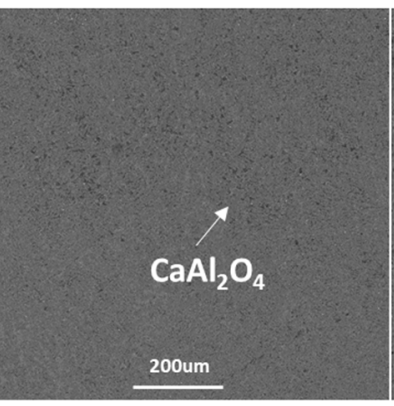

(b)

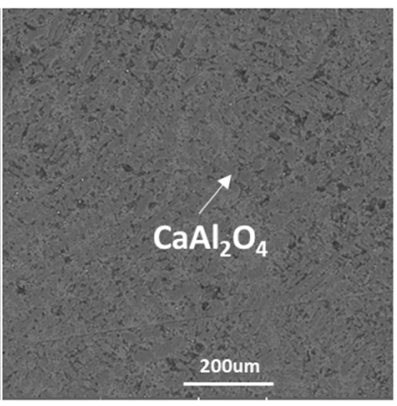

(c)

Figure 12. SEM micrographs of the $\mathrm{CaO}-\mathrm{Al}_{2} \mathrm{O}_{3}$-based mold flux after CSLM measurements: (a) $100{ }^{\circ} \mathrm{C} \cdot \mathrm{min}^{-1}$, (b) $300{ }^{\circ} \mathrm{C} \cdot \mathrm{min}^{-1}$, and (c) $500{ }^{\circ} \mathrm{C} \cdot \mathrm{min}^{-1}$.

The CSLM results showed that the morphology of $\mathrm{CaAl}_{2} \mathrm{O}_{4}$ was first dendritic, and then the dendritic morphology gradually changed to a large-mesh blocky shape at the cooling rates of $100^{\circ} \mathrm{C} \cdot \mathrm{min}^{-1}, 200^{\circ} \mathrm{C} \cdot \mathrm{min}^{-1}$, and $500{ }^{\circ} \mathrm{C} \cdot \mathrm{min}^{-1}$. The whole crystallization process was extremely rapid. This rapid crystallization process indicated that the crystallization ability of the $\mathrm{CaO}-\mathrm{Al}_{2} \mathrm{O}_{3}-\mathrm{based}$ mold flux is very strong. Different cooling rates did not show an obvious impact on the morphology transition of $\mathrm{CaAl}_{2} \mathrm{O}_{4}$.

Compared with that of the $\mathrm{CaO}-\mathrm{SiO}_{2}-\mathrm{CaF}_{2}$-based mold flux, the crystallization temperature of the $\mathrm{CaO}-\mathrm{Al}_{2} \mathrm{O}_{3}$-based mold flux was higher. This indicated that the crystal growth of the 
$\mathrm{CaO}-\mathrm{Al}_{2} \mathrm{O}_{3}$-based mold flux started at a higher temperature, so the crystallization was stronger than that of the $\mathrm{CaO}-\mathrm{SiO}_{2}-\mathrm{CaF}_{2}$-based mold flux. Many references have reported that the $\mathrm{CaO}-\mathrm{Al}_{2} \mathrm{O}_{3}$-based mold flux has a stronger crystallization ability than the $\mathrm{CaO}-\mathrm{SiO}_{2}$-based mold flux $[13,27]$. Our result is in agreement with these previous reports. The strong crystallization ability and the large rate of crystallization affected the control of heat transfer during casting. The big morphology difference between the primary crystals of the $\mathrm{CaO}-\mathrm{SiO}_{2}-\mathrm{CaF}_{2}$-based mold flux and the $\mathrm{CaO}-\mathrm{Al}_{2} \mathrm{O}_{3}$-based mold flux is probably one of the biggest factors limiting lubrication between the $\mathrm{CaO}-\mathrm{Al}_{2} \mathrm{O}_{3}$-based mold flux and high-Al steel during casting.

\section{Conclusions}

The effect of the cooling rate on the phase and crystal morphology transitions of a $\mathrm{CaO}-\mathrm{SiO}_{2}-\mathrm{CaF}_{2}$-based mold flux and a $\mathrm{CaO}-\mathrm{Al}_{2} \mathrm{O}_{3}$-based mold flux was investigated. The following conclusions were obtained:

1. Faceted cuspidine and $\mathrm{CaSiO}_{3}$ are co-precipitated when the cooling rate is less than $50{ }^{\circ} \mathrm{C} \cdot \mathrm{min}^{-1}$ in a traditional $\mathrm{CaO}-\mathrm{SiO}_{2}-\mathrm{CaF}_{2}$-based mold flux. The different cooling rates can change the phases and crystal morphologies. The phases transform from $\mathrm{Ca}_{4} \mathrm{Si}_{2} \mathrm{O}_{7} \mathrm{~F}_{2}$ and $\mathrm{CaSiO}_{3}$ to $\mathrm{Ca}_{4} \mathrm{Si}_{2} \mathrm{O}_{7} \mathrm{~F}_{2}$ as the cooling rate increases from $30^{\circ} \mathrm{C} \cdot \mathrm{min}^{-1}$ to $50{ }^{\circ} \mathrm{C} \cdot \mathrm{min}^{-1}$. Cuspidine shows four different morphologies: faceted shape, fine stripe, fine stripe dendrite, and flocculent dendrite.

2. $\mathrm{CaAl}_{2} \mathrm{O}_{4}$ and $\mathrm{Ca}_{3} \mathrm{~B}_{2} \mathrm{O}_{6}$ are co-precipitated in the $\mathrm{CaO}-\mathrm{Al}_{2} \mathrm{O}_{3}$-based mold flux. Neither the phases nor the crystal morphologies are altered as the cooling rate increases from $5^{\circ} \mathrm{C} \cdot \mathrm{min}^{-1}$ to $50{ }^{\circ} \mathrm{C} \cdot \mathrm{min}^{-1}$. The morphology of $\mathrm{CaAl}_{2} \mathrm{O}_{4}$ was firstly dendritic, and then the dendritic morphology gradually changed to a large-mesh blocky shape at the cooling rates of $100{ }^{\circ} \mathrm{C} \cdot \mathrm{min}^{-1}$, $200{ }^{\circ} \mathrm{C} \cdot \mathrm{min}^{-1}$, and $500{ }^{\circ} \mathrm{C} \cdot \mathrm{min}^{-1}$. Different cooling rates do not show an obvious impact on the morphology transitions of $\mathrm{CaAl}_{2} \mathrm{O}_{4}$.

3. The strong crystallization ability and the large rate of crystallization of the $\mathrm{CaO}-\mathrm{Al}_{2} \mathrm{O}_{3}$-based mold flux affect the control of heat transfer during casting. The big morphology difference between the primary crystals of the $\mathrm{CaO}-\mathrm{SiO}_{2}-\mathrm{CaF}_{2}$-based mold flux and the $\mathrm{CaO}-\mathrm{Al}_{2} \mathrm{O}_{3}$-based mold flux is probably one of the biggest factors limiting lubrication between the $\mathrm{CaO}-\mathrm{Al}_{2} \mathrm{O}_{3}$-based mold flux and high-Al steel during casting.

Author Contributions: Conceptualization, J.L.; Methodology, M.L.; Software, F.L.; Validation, J.L., M.L. and F.L.; Formal Analysis, M.L.; Investigation, M.L.; Resources, J.L.; Data Curation, J.L.; Writing一Original Draft Preparation, M.L.; Writing-Review \& Editing, J.L.; Visualization, J.L.; Supervision, J.L.; Project Administration, J.L.; Funding Acquisition, J.L.

Funding: This research was funded by [Natural Science Foundation of China] grant number [51704050], [China Postdoctoral Science Foundation] grant number [2018T110944], [Fundamental Research Funds for the Central Universities] grand number [2018CDXYCL0018] and [Chongqing Postdoctoral Science Foundation] grand number [Xm2017190].

Acknowledgments: Financial support from Natural Science Foundation of China (NSFC contract no. 51704050), China Postdoctoral Science Foundation (Project no: 2018T110944), Fundamental Research Funds for the Central Universities (Project no: 2018CDXYCL0018), and Chongqing Postdoctoral Science Foundation (Project no: Xm2017190) is gratefully acknowledged.

Conflicts of Interest: The authors declare no conflict of interest.

\section{References}

1. Mills, K.C.; Fox, A.B.; Li, Z.; Thackray, R.P. Performance and properties of mould fluxes. Ironmak. Steelmak. 2005, 32, 26-34. [CrossRef]

2. Heulens, J.; Blanpain, B.; Moelans, N. Analysis of the isothermal crystallization of $\mathrm{CaSiO}_{3}$ in a $\mathrm{CaO}-\mathrm{Al}_{2} \mathrm{O}_{3}-\mathrm{SiO}_{2}$ melt through in situ observations. J. Eur. Ceram. Soc. 2011, 31, 1873-1879. [CrossRef]

3. Hill, R.G.; Costa, N.D.; Law, R.V. Characterization of a mould flux glass. J. Non-Cryst. Solids 2005, 351, 69-74. [CrossRef] 
4. Nakada, H.; Susa, M.; Seko, Y.; Hayashi, M.; Nagata, K. Mechanism of Heat Transfer Reduction by Crystallization of Mold Flux for Continuous Casting. ISIJ Int. 2008, 48, 446-453. [CrossRef]

5. Cho, J.; Shibata, H.; Emi, T.; Suzuki, M. Radiative Heat Transfer through Mold Flux Film during Initial Solidification in Continuous Casting of Steel. ISIJ Int. 2007, 38, 268-275. [CrossRef]

6. Mizuno, H.; Esaka, H.; Shinozuka, K.; Tamura, M. Analysis of the crystallization of mold flux for continuous casting of steel. ISIJ Int. 2008, 48, 277-285. [CrossRef]

7. Yamauchi, A.; Sorimachi, K.; Sakuraya, T.; Fujii, T. Heat transfer between mold and strand through mold flux film in continuous casting of steel. ISIJ Int. 1993, 33, 140-147. [CrossRef]

8. Hanao, M.; Kawamoto, M.; Watanabe, T. Influence of $\mathrm{Na}_{2} \mathrm{O}$ on phase relation between mold flux composition and cuspidine. ISIJ Int. 2004, 44, 827-835. [CrossRef]

9. Guo, J.; Seo, M.-D.; Shi, C.-B.; Cho, J.-W.; Kim, S.-H. Control of Crystal Morphology for Mold Flux During High-Aluminum AHSS Continuous Casting Process. Metall. Mater. Trans. B 2016, 47, 2211-2221. [CrossRef]

10. Zhou, L.; Wang, W.; Ma, F.; Li, J.; Wei, J.; Matsuura, H.; Tsukihashi, F. A Kinetic Study of the Effect of Basicity on the Mold Fluxes Crystallization. Metall. Mater. Trans. B 2012, 43, 354-362. [CrossRef]

11. Li, J.; Shu, Q.; Hou, X.; Chou, K. Effect of $\mathrm{TiO}_{2}$ Addition on Crystallization Characteristics of $\mathrm{CaO}-\mathrm{Al}_{2} \mathrm{O}_{3}$-based Mould Fluxes for High Al Steel Casting. ISIJ Int. 2015, 55, 830-836. [CrossRef]

12. Zhang, Z.T.; Jing, L.I.; Peng, L.I.U. Crystallization Behavior in Fluoride-Free Mold Fluxes Containing $\mathrm{TiO}_{2} / \mathrm{ZrO}_{2}$. J. Iron Steel Res. Int. 2011, 18, 31-37. [CrossRef]

13. Cho, J.-W.; Blazek, K.; Frazee, M.; Yin, H.; Park, J.H.; Moon, S.-W. Assessment of CaO- $\mathrm{Al}_{2} \mathrm{O}_{3}$ Based Mold Flux System for High Aluminum TRIP Casting. ISIJ Int. 2013, 53, 62-70. [CrossRef]

14. Zhang, Z.T.; Wen, G.H.; Liao, J.L.; Sridhar, S. Observations of Crystallization in Mold Slags with Varying $\mathrm{Al}_{2} \mathrm{O}_{3} / \mathrm{SiO}_{2}$ Ratio. Steel Res. Int. 2010, 81, 516-528. [CrossRef]

15. Kashiwaya, Y.; Cicutti, C.E.; Cramb, A.W. An investigation of the crystallization of a continuous casting mold slag using the single hot thermocouple technique. ISIJ Int. 1998, 38, 357-365. [CrossRef]

16. Li, J.; Kong, B.; Galdino, B.; Xu, J.; Chou, K.; Liu, Q.; Shu, Q. Investigation on Properties of Fluorine-Free Mold Fluxes Based on $\mathrm{CaO}-\mathrm{Al}_{2} \mathrm{O}_{3}-\mathrm{B}_{2} \mathrm{O}_{3}$ System. Steel Res. Int. 2017, 88, 1600485. [CrossRef]

17. Yang, C.; Wen, G.; Sun, Q.; Tang, P. Evolution of Temperature and Solid Slag Film During Solidification of Mold Fluxes. Metall. Mater. Trans. B 2017, 48, 1292-1307. [CrossRef]

18. Kölbl, N.; Harmuth, H. Single hot thermocouple technique for the characterization of the crystallization behavior of transparent or translucent liquids. J. Mater. Sci. 2011, 46, 6248-6254. [CrossRef]

19. Seo, M.D.; Shi, C.B.; Cho, J.W.; Kim, S.H. Crystallization Behaviors of $\mathrm{CaO}-\mathrm{SiO}_{2}-\mathrm{Al}_{2} \mathrm{O}_{3}-\mathrm{Na}_{2} \mathrm{O}-$ $\mathrm{CaF}_{2}-\left(\mathrm{Li}_{2} \mathrm{O}-\mathrm{B}_{2} \mathrm{O}_{3}\right)$ Mold Fluxes. Metall. Mater. Trans. B 2014, 45, 1874-1886. [CrossRef]

20. Li, J.; Shu, Q.; Chou, K. Phase Relations in $\mathrm{CaO}-\mathrm{SiO}_{2}-\mathrm{Al}_{2} \mathrm{O}_{3}-15$ mass pct $\mathrm{CaF}_{2}$ System at $1523 \mathrm{~K}\left(1250{ }^{\circ} \mathrm{C}\right)$. Metall. Mater. Trans. B 2014, 45, 1593-1599. [CrossRef]

21. Lu, Y.; Yang, G.; Liu, F.; Wang, H.; Zhou, Y. The transition of alpha-Ni phase morphology in highly undercooled eutectic Ni78.6Si21.4 alloy. EPL 2006, 74, 281-286. [CrossRef]

22. Shu, Q.; Wang, Z.; Klug, J.L.; Chou, K.; Scheller, P.R. Effects of $\mathrm{B}_{2} \mathrm{O}_{3}$ and $\mathrm{TiO}_{2}$ on Crystallization Behavior of Slags in $\mathrm{Al}_{2} \mathrm{O}_{3}-\mathrm{CaO}-\mathrm{MgO}-\mathrm{Na}_{2} \mathrm{O}-\mathrm{SiO}_{2}$ System. Steel Res. Int. 2013, 84, 1138-1145. [CrossRef]

23. Orrling, C.; Cramb, A.W.; Tilliander, A.; Kashiwaya, Y. Observations of the melting and solidification behavior of mold slags. Iron Steelmaker 2000, 27, 53-63.

24. Temkin, O.E. Phenomenological kinetics of the motion of a phase boundary. Soviet Phys. Crystallogr. 1971, 15, 767-772.

25. Kirkpatrick, R.J. Crystal growth from the melt: A review. Am. Mineral. 1975, 60, 798-814.

26. Shi, C.B.; Seo, M.D.; Cho, J.W.; Kim, S.H. Crystallization Characteristics of $\mathrm{CaO}-\mathrm{Al}_{2} \mathrm{O}_{3}$-Based Mold Flux and Their Effects on In-Mold Performance during High-Aluminum TRIP Steels Continuous Casting. Metall. Mater. Trans. B 2014, 45, 1081-1097. [CrossRef]

27. Yan, W.; Chen, W.; Yang, Y.; Lippold, C.; McLean, A. Effect of Slag Compositions and Additive on Heat Transfer and Crystallization of Mold Fluxes for High-Al Non-magnetic Steel. ISIJ Int. 2015, 55, 1000-1009. [CrossRef]

(C) 2018 by the authors. Licensee MDPI, Basel, Switzerland. This article is an open access article distributed under the terms and conditions of the Creative Commons Attribution (CC BY) license (http://creativecommons.org/licenses/by/4.0/). 